\title{
APLIKASI PERHITUNGAN NILAI KALORI BAHAN MAKANAN BERBASIS ANROID
}

\author{
Ucu Muhammad Afif ${ }^{1}$, Selly Purnama ${ }^{2}$ \\ ${ }^{1}$ Jurusan Pendidikan Jasmani, FKIP Universitas Siliwangi \\ ${ }^{2}$ Jurusan Pendidikan Jasmani, FKIP Universitas Siliwangi \\ email: ucumuhammadafif@unsil.ac.id ${ }^{1}$, sellypurnama@unsil.ac.id ${ }^{2}$
}

\begin{abstract}
Abstrak
Proporsi makanan sehat berimbang terdiri atas 60-70\% karbohidrat, 20-25\% lemak, dan $10-15 \%$ protein dari total kebutuhan energi perhari. Kita harus mengetahui jumlah kalori bahan makanan yang dimakan supaya sesuai dengan jumlah kebutuhan. Perkembangan teknologi sangat mempermudah dalam perhitungan nilai kalori bahan makanan dengan menggunakan aplikasi berbasis android. Tujuan membangun aplikasi perhitungan Nilai Kalori Bahan Makanan berbasis android ini supaya mempermudah mendapatkan informasi tentang kandungan kalori bahan makanan. Setelah mengetahui nilai kalorinya maka dengan mudah pula menyusun menu makanannya. Metode yang digunakan adalah Research and Development. Langkah-langkah penelitiannya sebagai berikut : potensi dan masalah, pengumpulan data, desain produk, validasi desain, revisi desain, uji coba produk, revisi produk, uji coba pemakaian, revisi produk, produksi masal. Aplikasi perhitungan nilai kalori bahan makanan ini sudah bisa di download di playstore. Ketika membuka aplikasi langsung pada menu penghitung kalori, selanjunya ada menu input dan output, proses dan clear. Pada menu input fungsinya untuk memasukan makanan. Pada menu output fungsinya adalah hasil dari proses penghitungan jenis makanan yang di input sebelumnya. Menu proses fungsinya untuk menghitung atau memproses dari apa yang diinput. Sedangkan clear fungsinya untuk menghapus data input maupun output yang sudah diproses.
\end{abstract}

Kata Kunci: Bahan Makanan, Kalori, Perhitungan

\begin{abstract}
The proportion of balanced healthy food consists of 60-70\% carbohydrates, 20-25\% fat, and 10-15\% protein from total daily energy requirements. We must know the number of calories of food eaten so that it matches the amount of needs. The development of technology greatly facilitates the calculation of the calorie value of food ingredients using an Android-based application. The purpose of building an Android-based food calorie value calculation application is to make it easier to get information about the calorie content of food. After knowing the calorie value, it is also easy to arrange the food menu. The method used is Research and Development. The steps of the research are as follows: potential and problems, data collection, product design, design validation, design revisions, product trials, product revisions, product trials, product revisions, mass production. This calorie value calculation application for foodstuffs can be downloaded at PlayStore. When opening the application directly on the calorie counter menu, there is always an input and output menu, process and clear. In the input menu function to enter food. On the output menu the function is the result of the process of counting the types of food that were previously input. The process menu functions to calculate or process what is inputted. While the clear function is to delete input and output data that has been processed.
\end{abstract}

Keywords: Foodstuff, Calories, Calculation 


\section{PENDAHULUAN}

Pedoman Gizi Seimbang (PGS) saat ini digunakan sebagai acuan perilaku sehat. Pedoman ini untuk menggantikan slogan 4 sehat 5 sempurna dan sudah diimplementasikan sejak tahun 1955 (Safitri et al., 2016). Proporsi makanan sehat berimbang terdiri atas $60-70 \%$ karbohidrat, $20-25 \%$ lemak, dan $10-15 \%$ protein dari total kebutuhan energi per hari (Surbakti, 2010). Prinsip gizi seimbang terdiri dari empat pilar yang pada dasarnya merupakan rangkaian upaya untuk menyeimbangkan antara gizi yang keluar dan gizi yang masuk dengan memonitor berat badan secara teratur. Empat pilar gizi seimbang adalah: 1) Mengkonsumsi makanan beragam, 2) Membiasakan Perilaku Hidup Bersih dan Sehat (PHBS), 3) Melakukan aktivitas fisik, dan 4) Mempertahankan dan memantau Berat Badan Normal (Nuzrina et al., 2020). Makanan memiliki peranan penting dalam kesehatan masyarakat

Beberapa instrument yang diperlukan dalam menghitung kalori bahan makanan adalah : 1) Nilai Kalori Makanan, 2) Daftar Komposisi Bahan Makanan (DKBM), dan 3)Ukuran Rumah Tangga (URT) (Afif, 2017). Nilai energi yang dihasilkan dari setiap bahan makanan berbeda-beda yaitu sebagai berikut: 1 gram karbohidrat mengandung 4 kalori, 1 gram protein mengandung 4 kalori, 1 gram lemak mengandung 9 kalori (Nugroho \& Priyatna, 2017). Daftar komposisi bahan makanan sangat berguna sebagai pembantu apabila kita ingin mengetahui jenis dan jumlah zat gizi dari suatu hidangan, ataupun jika kita akan menyusun hidangan dengan jumlah dan jenis zat gizi tertentu. Angka-angka yang tercantum dalam Tabel DKBM tersebut adalah jumlah masing-masing zat gizi yang terdapat dalam setiap 100gram bahan makanan mentah dari bagian yang dapat dimakan. Contohnya dalam daftar tercantum beras mengandung 6,8gram protein, artinya setiap 100gram beras mengandung 6,8 protein. Daftar Ukuran Rumah Tangga (DURT) adalah daftar yang memuat satuan jumlah pangan atau makanan, berupa peralatan dan ukuran yang lazim digunakan di rumah seharihari, seperti piring, gelas, sendok, mangkok, potong, buah, ikat dll (Yosephin, 2018). DURT ini digunakan untuk menaksir jumlah bahan makanan kedalam gram.

Pentingnya mengetahui makanan yang dikonsumsi beserta kandungan gizi yang terdapat pada masing-masing makanan membantu orang tersebut untuk mengontrol kebutuhan kalori yang sesuai (Triyanti, 2010). Seiring berkembangnya Ilmu pengetahuan dan teknologi sangat membantu untuk mempermudah perhitungan nilai kalori bahan makanan dengan menggunakan aplikasi yang berbasis android.

Menurut Mulyadi (2010:5) dalam (Ramadhan \& Utomo G, 2014) menerangkan Android merupakan subset perangkat lunak untuk perangkat mobile yang meliputi sistem operasi, middleware dan aplikasi yang di release oleh Google. Ponsel memberikan dampak yang signifikan pada konsumen dan gaya hidup masyarakat, banyak aplikasi dan layanan telah dikembangkan dan disediakan di ponsel.

Beberapa penelitian tentang kalori bahan makanan sudah pernah dilakukan. Salah satunya adalah: 1) Lailatul Fitri Kanthi Sukasdi (2014) tentang "Rancang Bangun Aplikasi Penentuan Bahan Makanan Berdasarkan Status Gizi Pada Pasien Rawat Jalan", penelitian tersebut bertujuan menghasilkan aplikasi penentuan bahan mmakanan berdasarkan status gizi pada pasien rawat jalan berbasis web yang dapat menentukan status gizi, kebutuhan kalori dan bahan makanan untuk pasien rawat jalan dengan riwayat penyakit tertentu, 2) Andi Nugroho, Septian Galih Priyatna (2017) tetang Aplikasi Manajemen Restoran Dengan Perhitungan Jumlah 
Kalori Pada Daftar Menu”, penelitian tersebut bertujuan a) Menganalisa, merancang dan membuat sistem manajemen resto berbasis web pada cafe Rigth Time untuk menunjang jalannya operasional sehari-hari, b) Membuat terobosan baru dengan membuat daftar menu yang berisikan nilai kalori sebagai daya tarik pengunjung., c) Membuat cafe Rigth Time menjadi cafe dengan peduli terhadap nutrisi pada sajian. Kedua penelitian di atas sama-sama untuk menentukan kalori bahan makanan akan tetapi masih berbasis web. Penelitian ini diharapkan dapat bermanfaat bagi para praktisi olahraga dan masyarakat dalam menghitung kalori makanan yang dimakan dalam setiap harinya.

\section{BAHAN DAN METODE/METODOLOGI}

Penelitian ini menggunakan metode penelitian dan pengembangan atau Research and Development. Untuk mengetahui tingkat kelayakan aplikasi perhitungan kalori bahan bahan makanan berbasis android yaitu melalui validasi oleh ahli materi, validasi oleh media dan uji coba pengguna kepada masyarakat. Penelitian ini dilaksanakan dari bulan Mei- Nopember 2019.

Prosedur penelitian yang penulis gunakan mengacu kepada langkahlangkah metode Research and Development Sugiyono (Sugiyono, 2016), lebih jelasnya dapat dilihat pada gambar sebagai berikut :

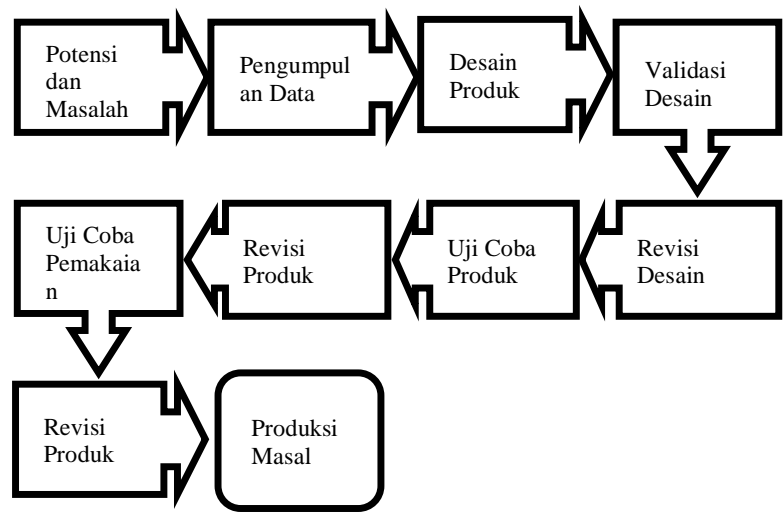

Gambar 1. Langkah-langkah

Penggunaan Metode Research and Development

(R \& D).(Sugiyono, 2016)

Subjek penelitian untuk uji coba adalah sasaran pemakaian produk yaitu sebanyak 20 orang pengguna $\mathrm{hp}$ android dengan berbagai macam merk dan tipe. Tahap-tahap dalam uji coba produk ini antara lain: (1) menetapkan desain uji coba, (2) menetapkan subyek uji coba (3) uji coba produk

Keabsahan data yaitu pada uji validitas dan reabilitas. Validitas dan reabilitas di dalam penelitian dan pengembangan perhitungan nilai kalori bahan makanan berbasis android ini adalah data yang diperoleh melalui kegiatan uji coba yang diklasifikasikan menjadi dua, yaitu data kuantitatif dan kualitatif. Data kualitatif berupa kritik saran yang dikemukakan oleh ahli media dan ahli materi, dan masyarakat. Sedangkan, data kuantitatif yang akan diubah menjadi kualitatif. Data tersebut digunakan untuk memberi gambaran mengenai kualitas aplikasi perhitungan kebutuhan energi atlet berbasis android.

Teknik analisis data kuantitatif dalam penelitian ini menggunakan analisis stastistik deskriptif, yang berupa pernyataan sangat kurang, kurang, cukup baik, baik dan sangat baik yang diubah menjadi data kuantitatif dengan skala 5 yaitu dengan penskoran dai angka 1 sampai 5. Langkah-langkah dalam analisis data antara lain: mengumpulkan data kasar, pemberian skor, skor yang diperoleh kemudian dikonversikan menjadi nilai dengan skala 5 .

\section{HASIL DAN PEMBAHASAN}

Tahapan pengumpulan informasi diawali dengan melakukan pengumpulan informasi berupa materi yang dikembangkan dalam aplikasi penghitungan nilai kalori bahan makanan berbasis android. Setelah materi yang dikembangkan sudah ditentukan maka 
langkah selanjutnya adalah melakukan studi pustaka untuk mengumpulkan materi 1) Nilai kalori makan, 2) Daftar Komposisi Bahan Makanan, dan 3) Ukuran Rumah Tangga (Afif, 2017).

Pada tahapan kedua terdiri dari pembuatan kisi-kisi instrumen. Kisi-kisi instrument kemudian dikembangkan menjadi instrumen penelitian. Instrumen penelitian yang digunakan adalah lembar validasi, lembar observasi dan pedoman wawancara. Lembar validasi digunakan untuk mengetahui kelayakan aplikasi berdasarkan penilaian ahli materi dan ahli media.

Tahap ke tiga adalah pembuatan dan pengembangan produk. Pada tahap ini, sudah dibuat tampilan menu utama atau halaman utama yang terdiri dari nama aplikasi yaitu Penghitung Kalori Makanan yang terdapat pada bagian header. Selain itu terdapat juga 3 tombol menu yang tersedia yaitu tombol tutorial aplikasi, menu makan, dan penghitung kalori. utama :

Berikut ini tampilan halaman
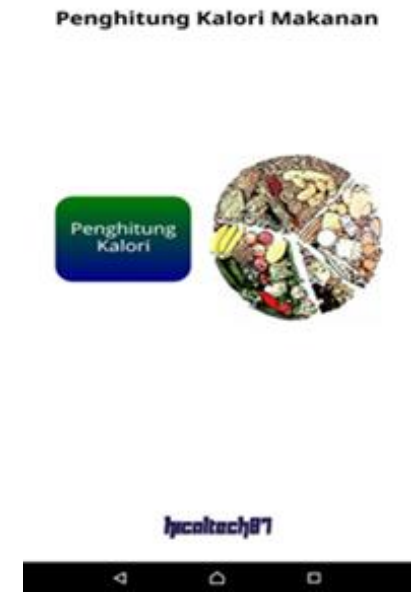

Gambar 2. Tampilan Halaman Utama Aplikasi

\section{Pilihan Menu Pada Halaman Penghitung Kalori}

Pada halaman Penghitung Kalori Makanan, terdapat 2 bagian yaitu INPUT dan OUTPUT. Kedua bagian tersebut memiliki fitur layar yang bisa digulirkan (scroll) ke bawah dan ke atas. 2 bagian pada halaman tersebut terdiri dari bagian INPUT yang berada di bagian atas layar. Pada bagian INPUT terdiri dari beberapa menu pilihan yang harus diisi oleh pengguna yaitu :

\section{Makanan Pokok}

Pada menu ini, terdapat beberapa macam jenis bahan makanan pokok yang bisa dipilih oleh pengguna dengan cara melakukan klik pada tulisan pilih makanan pokok sehingga nanti akan muncul pilihan makanan pokok. Jenis makanan pokok dalam aplikasi ini terdiri dari 17 jenis makanan yaitu : Bihun, Havermut, Jagung Segar, Kentang, Makaroni, Mie Basah, Mie Kering, Nasi Beras Giling Merah, Nasi Beras Giling Putih, Roti Putih, Singkong, Talas, Tape Singkong, Tepung Beras, Tepung Sagu, Tepung Tapioka, Tepung Terigu.

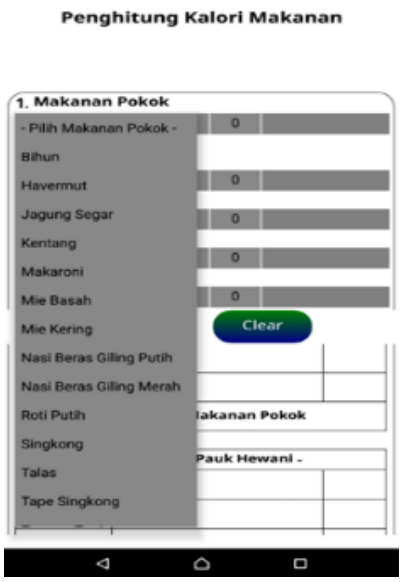

Gambar 3. Tampilan Menu Pilihan Makanan Pokok

\section{Lauk Pauk}

Pada menu lauk pauk terdiri dari jenis makanan hewani dan nabati. Pada menu ini, pengguna akan melihat pilihan menu lauk pauk hewani sebanyak 38 jenis makanan. Sedangkan pilihan menu 
untuk lauk pauk nabati terdiri dari 9 macam jenis makanan. Untuk melihat jenis makanan lauk pauk baik hewani maupun nabati, maka pengguna cukup menekan tulisan "- Pilih Lauk Hewani -“ dan "- Pilih Pauk Nabati -“.

Berikut adalah jenis makanan lauk pauk hewani dan nabati yang tersedia di aplikasi ini ; 1) Jenis Makanan Lauk Hewani yaitu : Babat, Bebek, Belut, Daging asap, Daging ayam, Daging babi, Daging kambing ,Daging kerbau, Daging sapi, Dendeng sapi, Gabus kering, Ginjal sapi, Hati sapi, Ikan asin kering, Ikan cakalang asin, Ikan kakap, Ikan kembung, Ikan lemuru, Ikan mas, Ikan pindang, Ikan segar, Kerang, Kornet daging sapi, Kuning telur ayam, Otak, Putih telur ayam, Rebon basah, Rebon kering, Sardencis, Selar kering, Sepat kering, Sosis, Telur ayam, Telur bebek, Telur bebek asin, Teri nasi, Udang segar, Usus sapi; 2) Jenis Makanan Lauk Nabati yaitu : Kacang Hijau, Kacang Kedelai , Kacang Tanah Kupas, Keju Kacang Tanah, Oncom, Petai Segar, Tahu, Tempe, Sari Kedelai.

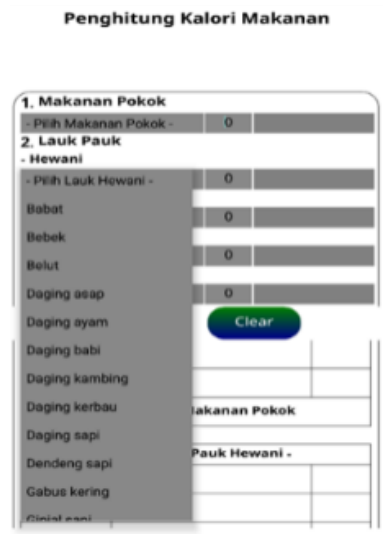

Gambar 4. Tampilan Menu Pilihan Lauk Hewani

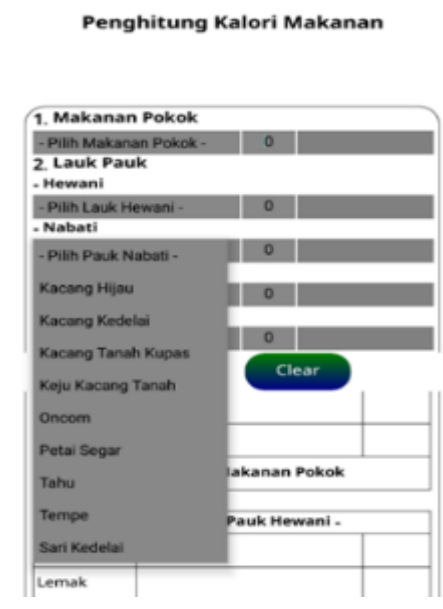

Gambar 5. Tampilan Menu Pilihan Pauk Nabati

\section{Sayuran}

Pada menu sayuran, pengguna diberikan beberapa pilihan jenis makanan sayuran sebanyak 31 jenis sayuran yang dapat dilihat dengan cara menekan tulisan pada menu sayuran "Pilih Sayuran -“.

Berikut ini jenis sayuran yang terdapat pada aplikasi ini yaitu : Bayam, Bayam merah, Bit, Buncis, Daun kacang panjang, Daun katuk, Daun kecipir, Daun melinjo, Daun papaya, Daun singkong, Genjer, Jagung muda, Kacang kapri, Kacang panjang, Kangkung, Kemangi, Kembang kol, Kol, Labu Siam, Labu waluh, Daun Mangkokan, Melinjo, Nangka muda, Pare Paria, Pepaya muda, Rebung, Sawi, Taoge, Taoge kedelai, Terong, Wortel.

Penghitung Kalori Makanan

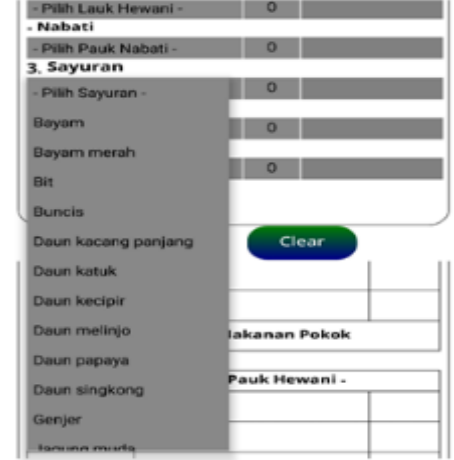


Gambar 6. Tampilan Menu Pilihan Sayuran

\section{Buah}

Pada menu buah, pengguna diberikan beberapa pilihan jenis buah sebanyak 30 jenis yang dapat dilihat dengan cara menekan tulisan pada menu buah "- Pilih Buah -“.

Berikut ini jenis buah yang terdapat pada aplikasi ini yaitu : Alpukat, Apel merah, Apel malang, Belimbing, Duku, Durian, Jambu air, Jambu biji, Jambu bol, Jeruk bali, Jeruk garut , Jeruk manis, Jeruk nipis, Kedondong , Kesemek, Mangga, Manggis, Markisa, Nangka masak, Nanas, Pepaya, Pisang ambon, Pisang mas , Pisang raja, Rambutan, Sawo, Salak, Semangka, Sirsak, Srikaya.

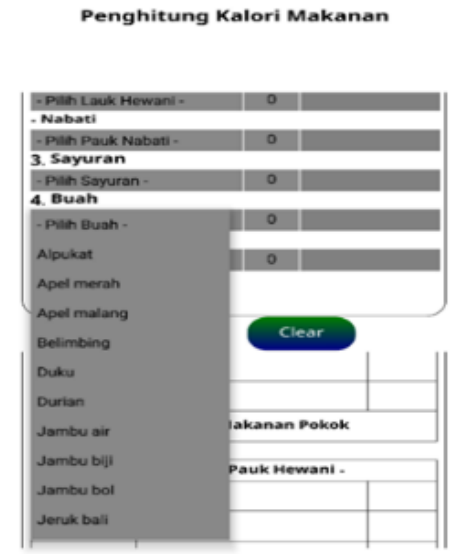

Gambar 7. Tampilan Menu Pilihan Buah

\section{Pelengkap}

Pada menu pelengkap, pengguna diberikan beberapa pilihan jenis makanan pelengkap sebanyak 9 jenis makanan, yang dapat dilihat dengan cara menekan tulisan pada menu pelengkap "Pilih Makanan Pelengkap -“.

Berikut ini jenis makanan pelengkap yang terdapat pada aplikasi ini yaitu : Keju, Susu Kambing,Susu Kental Manis, Susu Kental Tidak Manis, Susu Kerbau, Susu Sapi, Susu Skim Cair, Yoghurt Non Fat, Yoghurt Susu Penuh.

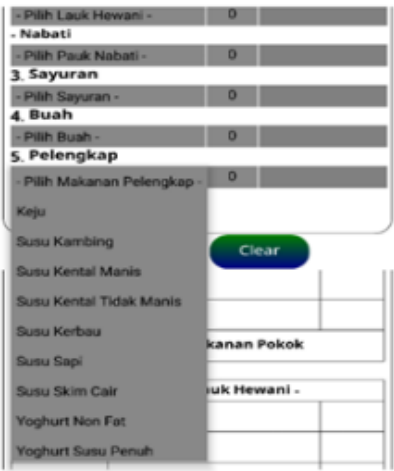

Gambar 8. Tampilan Menu Pilihan Makanan Pelengkap

\section{Proses Output Data Kalori Makanan}

Untuk mengetahui jumlah kalori dari tiap jenis makanan, maka pengguna harus memilih pilihan makanan yang berada pada bagian INPUT. Setelah semua pilihan terisi, kemudian pengguna menekan tombol PROSES yang berada di tengah layar diantara bagian INPUT (Layar Bagian Atas) dan Output (Layar Bagian Bawah).

Hasil dari menekan tombol proses akan ditampilkan pada bagian OUTPUT secara detail sesuai dengan jenis kategori makanan. Berikut ini tampilan halaman output untuk setiap jenis kategori makanan :

Penghitung Kalori Makanan

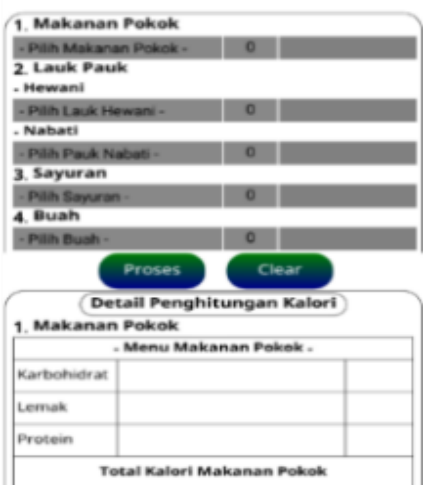

Gambar 9. Tampilan Output Makanan Pokok 
Penghitung Kalori Makanan

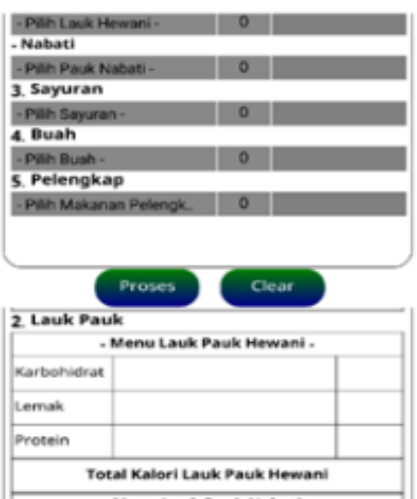

Gambar 10. Tampilan Output Lauk Pauk

Penghitung Kalori Makanan

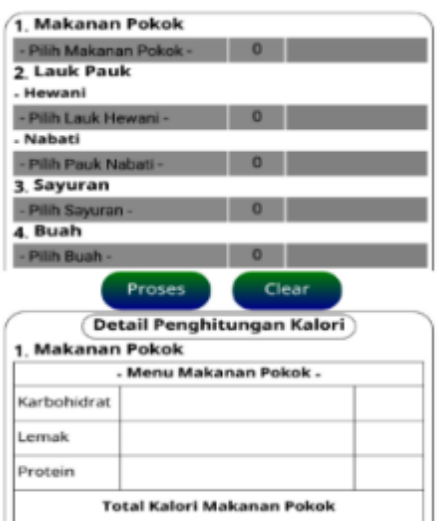

Gambar 11. Tampilan Output Makanan Pokok

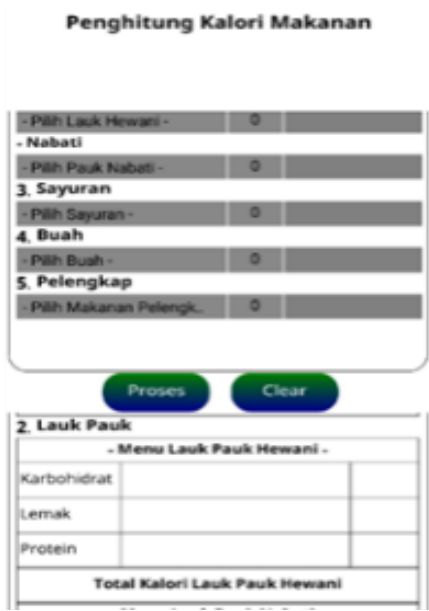

Gambar 12. Tampilan Output Lauk Pauk
Penghitung Kalori Makanan

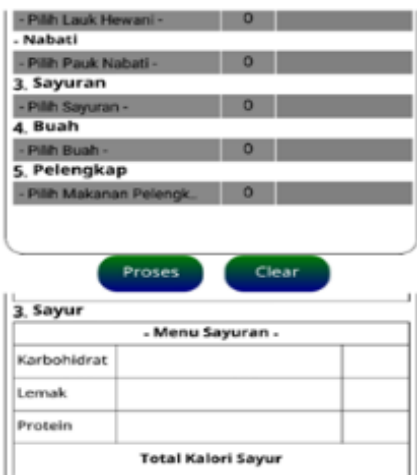

Gambar 13. Tampilan Output Sayuran

Penghitung Kalori Makanan

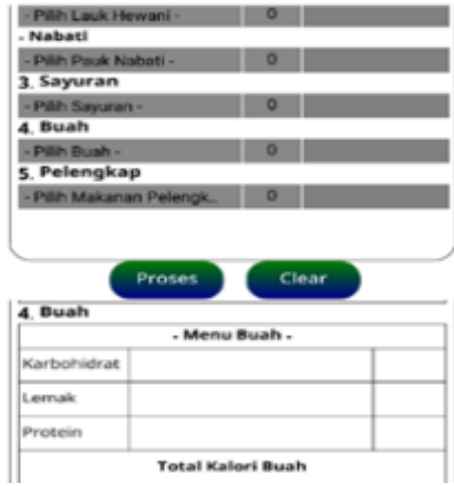

Gambar 14. Output Buah

Penghitung Kalori Makanan

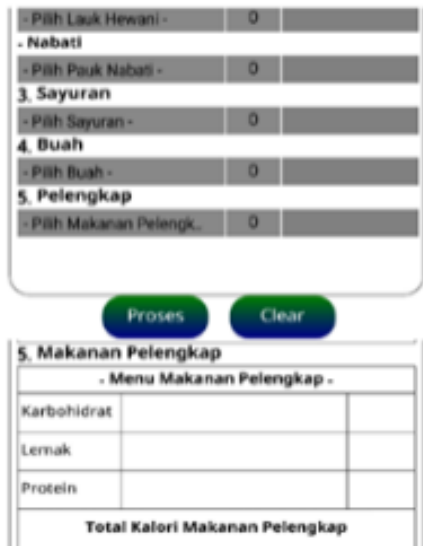

Gambar 15. Makanan Pelengkap 
Tahap validasi dilakukan agar aplikasi penghitungan kalori bahan makanan yang dirancang dan dikembangkan dapat diketahui kelayakannya berdasarkan penilaian ahli materi dan ahli media. Validasi aplikasi dilakukan oleh: 1) ahli materi yang berkompeten di bidang Ilmu Gizi Olahraga; dan 2) ahli media yang berkompeten dalam bidang aplikasi yang berbasis android.

Produk aplikasi yang sudah divalidasi selanjutnya direvisi sesuai dengan saran dan masukan ahli saat proses validasi. Setelah aplikasi selesai direvisi kemudian dilakukan tahap uji coba yang dilakukan kepada masyarakat yang ada di lingkungan Kota Tasikmalaya. Selama tahap uji coba

Peneliti melakukan observasi terhadap penggunaan aplikasi tersebut. Setelah masyarakat menggunakan aplikasi kemudian diwawancara untuk diminta tanggapan, saran, dan komentarnya mengenai aplikasi yang dikembangkan.

\section{Hasil Validasi Materi}

Sebelum melakukan uji coba, aplikasi penghitungan kebutuhan energi atlet yang dikembangkan divalidasi terlebih dahulu oleh ahli materi. Validasi materi dilakukan oleh Dosen Penjas

FKIP Universitas Siliwangi yang mempunyai bidang keilmuan sesuai dengan materi. Hasil validasi tersebut dapat dilihat pada tabel berikut:

Tabel Hasil Validasi

\begin{tabular}{cllc}
\hline No & Aspek & Indikator & Nilai \\
\hline 1 & Instruksional & $\begin{array}{l}\text { Terdapat } \\
\text { petunjuk } \\
\text { penggunaan } \\
\text { aplikasi }\end{array}$ & \\
& & 4 \\
& & $\begin{array}{l}\text { Kemudahan } \\
\text { memahami }\end{array}$ & 4 \\
& cara-cara & \\
& mengisi data \\
& & \\
& & yang akan di \\
& & \\
& & \\
& & \\
& & \\
& & & \\
& &
\end{tabular}

\begin{tabular}{|c|c|c|c|}
\hline 3 & Input Data & $\begin{array}{l}\text { Komponen } \\
\text { data yang } \\
\text { disajikan } \\
\text { dalam menu } \\
\text { sesuai } \\
\text { dengan } \\
\text { materi } \\
\text { penghitunga } \\
\text { n kalori } \\
\text { bahan } \\
\text { makanan }\end{array}$ & 3 \\
\hline 4 & Proses Data & $\begin{array}{l}\text { Langkah- } \\
\text { langkah } \\
\text { penghitunga } \\
\text { n sesuai } \\
\text { dengan } \\
\text { rumus } \\
\text { penghitunga } \\
\text { n yang } \\
\text { diungkapkan } \\
\text { para ahli gizi }\end{array}$ & 4 \\
\hline 5 & Kompatibilitas & $\begin{array}{l}\text { Kompatible } \\
\text { dengan } \\
\text { berbagai } \\
\text { macam tipe } \\
\text { smartphone } \\
\text { android }\end{array}$ & 3 \\
\hline 6 & Kompatibilitas & $\begin{array}{l}\text { Resolusi } \\
\text { layar bisa } \\
\text { beradaptasi } \\
\text { di posisi } \\
\text { portrait dan } \\
\text { landscape }\end{array}$ & 3 \\
\hline 7 & Kompatibilitas & $\begin{array}{l}\text { Tiap kolom } \\
\text { isian data } \\
\text { bisa dilihat } \\
\text { dengan jelas }\end{array}$ & 4 \\
\hline 8 & Kompatibilitas & $\begin{array}{l}\text { Ukuran file } \\
\text { aplikasi } \\
\text { tidak } \\
\text { memakan } \\
\text { banyak } \\
\text { ruang di } \\
\text { dalam } \\
\text { penyimpana } \\
\text { n memori } \\
\text { smartphone }\end{array}$ & 4 \\
\hline 9 & Output Data & $\begin{array}{l}\text { Hasil } \\
\text { penghitunga } \\
\text { n dapat } \\
\text { dengan }\end{array}$ & 4 \\
\hline
\end{tabular}




\begin{tabular}{lll}
\hline & mudah \\
& dipahami & \\
& oleh \\
& pengguna & \\
\hline $10 \quad$ Output Data & Data yang & 4 \\
& dihasilkan & \\
& terlihat jelas \\
& di layar \\
& smartphone \\
\hline
\end{tabular}

\section{Pembahasan}

Untuk mempermudah masyarakat dalam menyusun menu makanan yang sesuai dengan jumlah kebutuhan energi harian bisa dengan menggunakan aplikasi perhitungan kalori bahan makanan. Aplikasi ini di download terlebih dahulu di playstore. Setelah di download kemudian buka aplikasi untuk menggunakannya. Cara menggunakan aplikasi ini yaitu pengguna aplikasi pada saat membuka menu utama diharuskan mengisi semua pilihan makanan yang disesuaikan dengan menu makanannya. Setelah pilihan terisi semua, kemudian tekan tombol PROSES untuk mengetahui jumlah kalori dari makanan yang dimakan oleh pengguna aplikasi.

Setelah menekan tombol proses, maka akan muncul data hasil jumlah kalori tiap kategori jenis makanan dan total kalori dari makanan yang dimakan pada bagian OUTPUT yang berjudul Detail Kalori Makanan. Jika pengguna ingin menghapus pilihannya maka tekan tombol CLEAR yang ada di samping tombol PROSES.

Berbagai penelitian menunjukkan kebermanfaatan aplikasi ini sangat membantu bagi mereka yang ingin mengetahui jumlah asupan kalori yang dikonsumsi dari setiap kali makan. Dengan terjaganya jumlah kalori yang masuk ke tubuh diharapkan pengguna dapat memiliki berat badan yang ideal, terjaga kesehatannya dan terhindar dari penyakit-penyakit akibat mengonsumsi makanan dengan jumlah kalori yang tidak sesuai dengan kebutuhan tubuh (Haryanto, 2015), (Ajidarma, 2019), (Hasan et al., n.d.).

\section{KESIMPULAN DAN SARAN}

1. Pengguna bisa langsung menggunakan aplikasi perhitungan kalori bahan makanan setelah mendowload aplikasinya di playstore. Ketika membuka aplikasi langsung pada menu penghitung kalori, selanjutnya ada menu input dan output, proses dan clear.

2. Pada menu input fungsinya untuk memasukan makanan apa saja yang mau di konsumsi, terdiri dari: makanan pokok, lauk pauk, sayuran, buah-buahan dan pelengkap lainnya. Pada menu output fungsinya adalah hasil dari proses penghitungan jenis makanan yang di input sebelumnya.

3. Menu proses fungsinya untuk menghitung atau memproses dari apa yang diinput. Sedangkan clear fungsinya untuk menghapus data input maupun output yang sudah diproses.

\section{DAFTAR PUSTAKA}

Afif, U. M. (2017). Ilmu Gizi Olahraga. Langgam Pustaka.

Ajidarma, M. (2019). Aplikasi perhitungan kebutuhan kalori dan perhitungan kalori dari makanan yang dikonsumsi.

Haryanto, M. W. (2015). Aplikasi Penghitung Kebutuhan Kalori Harian Dan Daftar Kandungan Kalori Bahan Makanan. Tugas Akhir.

Hasan, I., Setiawan, E. B., Dipatiukur, J., Bandung, N., \& Barat, J. (n.d.). DEVELOPMENT OF FOOD RECOMMENDATION APPLICATION BASED ON CALORIE NEEDS USING AN ANDROID-BASED SMARTBAND Teknik Informatika - Universitas Komputer Indonesia. 2-9.

Hermawan, S. (2011). Mudah Membuat Aplikasi Android. Andi. 
Nugroho, A., \& Priyatna, S. G. (2017). Aplikasi manajemen restoran dengan penghitungan jumlah kalori pada daftar menu. Prosiding Seminar Nasional Inovasi Teknologi-, 217-234.

Nuzrina, R., Arjuna, J., Tol, U., \& Jeruk, K. (2020). Upaya Peningkatan Pengetahuan Mengenai Gizi Seimbang. 6(2), 5.

Ramadhan, T., \& Utomo G, V. (2014). Rancang Bangun Aplikasi Mobile Untuk. Jurnal Teknologi Informasi Dan Komunikasi, 5, 47-55. https://doi.org/10.1234/JTIK.V5I2. 93

Rao, D. V. S., \& Krishna, D. T. M. (2014). A Design of Mobile Health for Android Applications. American Journal of Engineering Research, 3(6), 20-29. www.ajer.org

Safaat, N. (2014). Android (Pemrograman Aplikasi Mobile Smartphone dan Tablet PC Berbasis Android. Informatika.

Safitri, A., Jahari, A. B., \& Ernawati, F. (2016). Konsumsi Makanan Penduduk Indonesia Ditinjau Dari Norma Gizi Seimbang. Penelitian Gizi Dan Makanan, 39(2), 87-94.

Sugiyono. (2016). Metode Penelitian Kuantitatif, Kualitatif, dan $R \& D$. Alfabeta.

Surbakti, S. (2010). Asupan Bahan Makanan Dan Gizi Bagi Atlet Renang. Jurnal Ilmu Keolahragaan, 8(2), 108-122.

Triyanti, D. (2010). Sistem informasi untuk menentukan kebutuhan makanan berdasarkan jumlah kalori.

Yosephin, B. (2018). Tuntunan Praktis Menghitung Kebutuhan Gizi. Andi. 